\title{
Designing lesson plan of integer number operation based on fun and easy math (FEM) approach
}

Darin Fouryza, Siti Maghfirotun Amin, Rooselyna Ekawati

Primary Education Study Program, Universitas Negeri Surabaya, Indonesia

\begin{tabular}{l}
\hline \hline Article Info \\
\hline Article history: \\
Received Sep 10, 2018 \\
Revised Dec 20, 2018 \\
Accepted Jan 26, 2019 \\
\hline
\end{tabular}

Keywords:

Fun and easy math (FEM)

Integer number operation

Lesson plan (RPP)

Number line model

Plomp's development model

\begin{abstract}
This paper dealt with the design of learning tools, that was the development of learning implementation plan or Rencana Pelaksanaan Pembelajaran (RPP) based on Fun and Easy Math (FEM) approach in the form of a number line model. FEM was an approach in order to teach mathematics effectively to students in a fun and easy way according to the patterns and rules, making it easier for students to understand mathematical concepts and driving them to actively participate in learning activity. Furthermore, the number line model based on the rules aimed to provide the real idea of mathematical concept and avoid the mathematical manipulation. The design of RPP development was intended to create a new RPP which was divided into three activities, namely introduction, core, and closing. The method of lesson plan development used a Plomp's development model which was consisted of three phases, namely preliminary research, prototype, and evaluation. The results of this development were expected to help students in understanding the mathematical concepts, namely integer calculation operations especially addition and subtraction, increasing student activeness in learning process, and avoiding the existence of mathematical manipulation.
\end{abstract}

Copyright (C) 2019 Institute of Advanced Engineering and Science. All rights reserved.

\section{Corresponding Author:}

Darin Fouryza,

Primary Education Study Program, Master Program

Universitas Negeri Surabaya,

Ketintang Surabaya, 60231, Indonesia

Email: darinfouryza16070855118@mhs.unesa.ac.id

\section{INTRODUCTION}

One of the objectives given to mathematics in elementary school is that students are able to understand mathematical concepts and interrelationship between the concepts, as well as apply the concept in a flexible, efficient, and appropriate way to solve daily problems, both concepts that have been learned and concepts that will be studied [1]. The concept understanding will be used by students as a preparation to take the next level of study and to solve daily problems [2]. Besides that, it will also be a basis for developing advanced abilities, such as the ability to apply mathematical concepts, use of mathematical reasoning, critical thinking, and problem solving [3]. Thus, the student's understanding about mathematical concept is one of the ability qualifications that must be achieved in mathematics subjects [1].

The concept of mathematics is basically one of the direct objects in addition to three other direct objects, namely facts, operations, and properties. The mathematics concept is an abstract idea that allows someone to classify an object or event and explain whether the object or event is an example or not [4]. Furthermore, the concept is generally composed by the previous concepts and facts. In order to show a particular concept, it is very important to provide limitations or definitions. This gives an idea that, generally, a concept can be used continuously to explain other concepts in mathematics, so that students can know, understand, and call object they know through the concept [5]. Consequently, the misconceptions that students receive can be fatal to learn further concepts. 
In the relation of elementary student's understanding concept, the most important thing to be noted is how students develop a concept in their cognitive structure. Without this principle, it cannot be expected that students understand the subject matter given by teacher.

One of mathematical concepts is integer number operation, especially addition and subtraction. In general, the definition of such concept is known by students from the environment directly, for example through the activities of buying and selling, profit, and loss, etc. Therefore, before studying at school, students have already understood the addition and subtraction operation of integer number in the physical objects. However, in fact, students still find the difficulty to understand the mathematical concept. The general difficulty is the recognition and understanding of symbols $(+,-,-)$, the differentiation of calculation operation function (addition and subtraction) with integer mark, and the replacement of negative numbers role [6]. For example, $7-(-3)=4$.

In order to understanding the concept of integer operations precisely and meaningfully, teacher's ability to plan learning in detail is highly required which is realized in the design of learning tools, namely the development of RPP through the use of FEM approach assisted by the number line model. It is in line with Mulyasa that an effective approach needs to be chosen to create a conducive and enjoyable learning environment, so that students can easily figure out abstract mathematical concept [7].

Introducing the concept of integer operation can be conducted through three stages, namely: 1) introduction of concept in concrete stage, 2) introduction of concept in semi-concrete (semi-abstract), 3) recognition of concept in abstract [8]. This is in line with Ausubel's opinion which argue that the formation of concept can occur to someone through demonstration. For example, children who generally know information about something from adult, such as knowing chairs, cat, pencil, and others.

Therefore, the descriptions presented by this paper are highly required by teachers and other readers since FEM approach itself is still not widely discussed. So, in this study, FEM will be applied to the operations of adding and subtraction of integer number for primary students, especially for fourth grade students with development research type assisted by number line. In addition, a good understanding about FEM approach and its implementation in the development of learning materials is the basic for creating a new lesson plan which is innovative and creative based on FEM.

\section{FUN AND EASY MATH (FEM) APPROACH}

FEM approach is a way to teach mathematical concepts easily and pleasantly based on patterns and rules [9]. This approach consists of four principles, namely simple, useful, relation, and fun. Four principles of FEM approach will be described below.

\subsection{Simple}

Simple is technique for teaching mathematics subject as easy as possible based on patterns and rules which are easily understood by students [9]. These patterns and rules are made, so that mathematical concept delivered by teacher is not difficult to be understood by students. Furthermore, the number line model based on the FEM approach is given in order to make mathematical concept easier to be learned.

\subsection{Useful}

Useful principle relates to how students know the important goals of learning mathematics, so that the learning becomes meaningful [9]. Learning with meaningfulness can help students to easily remember the mathematical concepts that have been learned and will be learned. In line with this, Jamaris explained that "mathematics has important worth for our daily life, because almost all region of life requires the application of mathematical ability, so without the best understanding of that, our life will be difficult [10].

\subsection{Relation}

The principle of relation means that the mathematical learning activities must be related to the experience or daily life of students [9]. This is conducted since it makes easy for student in understanding of mathematical concept and applying the concept in their daily life well. Moreover, by introducing learning mathematics concept through their daily life or daily life problems make learning mathematics more interesting and meaningful for students where the problems were in the student's knowledge and experience [11]. Explained that students usually don't enjoy learning activities well and can properly not apply mathematics in daily life when they sit passively and learn mathematics concept that are not relevant to their daily life [12]. Therefore, learning mathematics with related to student's daily life or their daily life problem is needed for this principle.

Int. J. Eval. \& Res. Educ. Vol. 8, No. 1, March 2019: 103 - 109 


\subsection{Fun}

The fun principle means that mathematical learning activities must be designed more fun, so that students are enthusiastic and have a high interest in learning mathematics. Hermansyah stated that the fun learning was indicated by not only the student's feeling of pleasure during mathematical learning but also the inner motivation to have further learning endurance [13]. This endurance can be realized if students know something, then they always want to find out more about this.

Furthermore, Griffiths stated that "children will become successful mathematicians if mathematics is delivered in a fun and useful way " [14]. This can certainly be done by teaching mathematical concepts using certain methods correctly and delivering the concept in a pleasant environment. Research by using the context of learning mathematich with fun to understand mathematics concept had been done as well [15].

Learning mathematics with fun is considered as a mechanism that can encourage student's concentration to more easily understand learning materials, increase motivation in learning, and provide convenience in receiving of various learning needs [16]. Thus, the fun principle in the FEM approach can be presented by playing games, giving rewards, giving motivation, and inviting students to sing.

\section{LESSON PLAN}

Lesson plan, called as Rencana Pelaksanaan Pembelajaran (RPP), is a guide of learning activities implementation for each meeting [17]. The learning activities are divided into three stages. Namely 1) introduction, 2) core, and 3) closing.

The preliminary activity aims to build student's readiness in carrying out classroom learning activities. These activities include prayer, giving motivation, apperception, and informing the learning objectives that will be conducted out.

The core activities are given by observing the principles of FEM approach. This activity includes delivering subject matter, forming study groups, group discussions, and presentation.

The closing activity is the final activity of a series of learning activities in the classroom. These activities include making summaries or conclusions from learning activities that have been carried out, evaluating, reflecting, delivering follow-up activities, and praying. RPP must be created based on the objectives that are stated in the curriculum, which is to establish independence and increase the student's learning motivation, as well as be student centered [18].

\section{METHOD}

The method used in this research is the method of development research refer to the development theory proposed by Plomp as depicted on Figure 1. That development was renewed and has three stages, namely preliminary research, prototyping phase, and evaluation phase [19]. Three stages in the development research will be described below.

\subsection{Phase I: Preliminary research stage}

The preliminary research is required to obtain the insight about the problems in education, i.e. about the gap between the current situation in field and the desired one. [19] Explained that the activities in this phase comprised of a study of needs and context analysis, a review of literature, and a development of conceptual or theoretical framework for the research. Therefore, the development of lesson plan in this phase only focuses on curriculum analysis activities, student analysis, material analysis, and task analysis.

\subsection{Phase II: Prototype}

The prototype phase is a follow-up activity of the preliminary research which is to find a solution from the preliminary research and then to realize the lesson plan into a prototype draft product. The activity of this phase consisted of (1) the realization of lesson plan into a prototype draft product by adjusting the four principles of FEM approach on the subject matter that is determined by integer calculation operations, and (2) the arrangement of research instrument in the form of validation sheet of lesson plan.

\subsection{Phase III: Evaluation}

The evaluation phase aims to ascertain whether the developed lesson plan has reached the criteria of a good quality lesson plan or not. The previously prepared draft (draft prototype) will be validated by the validators and revised until the valid prototype is created. So, the activities that have to be conducted in this phase include validation, test legibility, and field trials.

The determination of the quality of the development of the lesson plan basically requires three criteria as proposed by Nieveen, namely validity, practically, and effectiveness [20].

Designing Lesson Plan of Integer Number Operation based on Fun and Easy Math... (Darin Fouryza) 
Validity refers to the truth, significance, and usefulness of the specific conclusions the researchers made based on the data already collected to measure the lesson plan that developed valid or not [21]. Thus, the lesson plan in this study is valid if it has a strong theoretical rationale (content validity) and all device components are consistently connected with others in harmony (construct validity) [22]. The framework of thinking about the development of learning materials is shown in Figure 1.

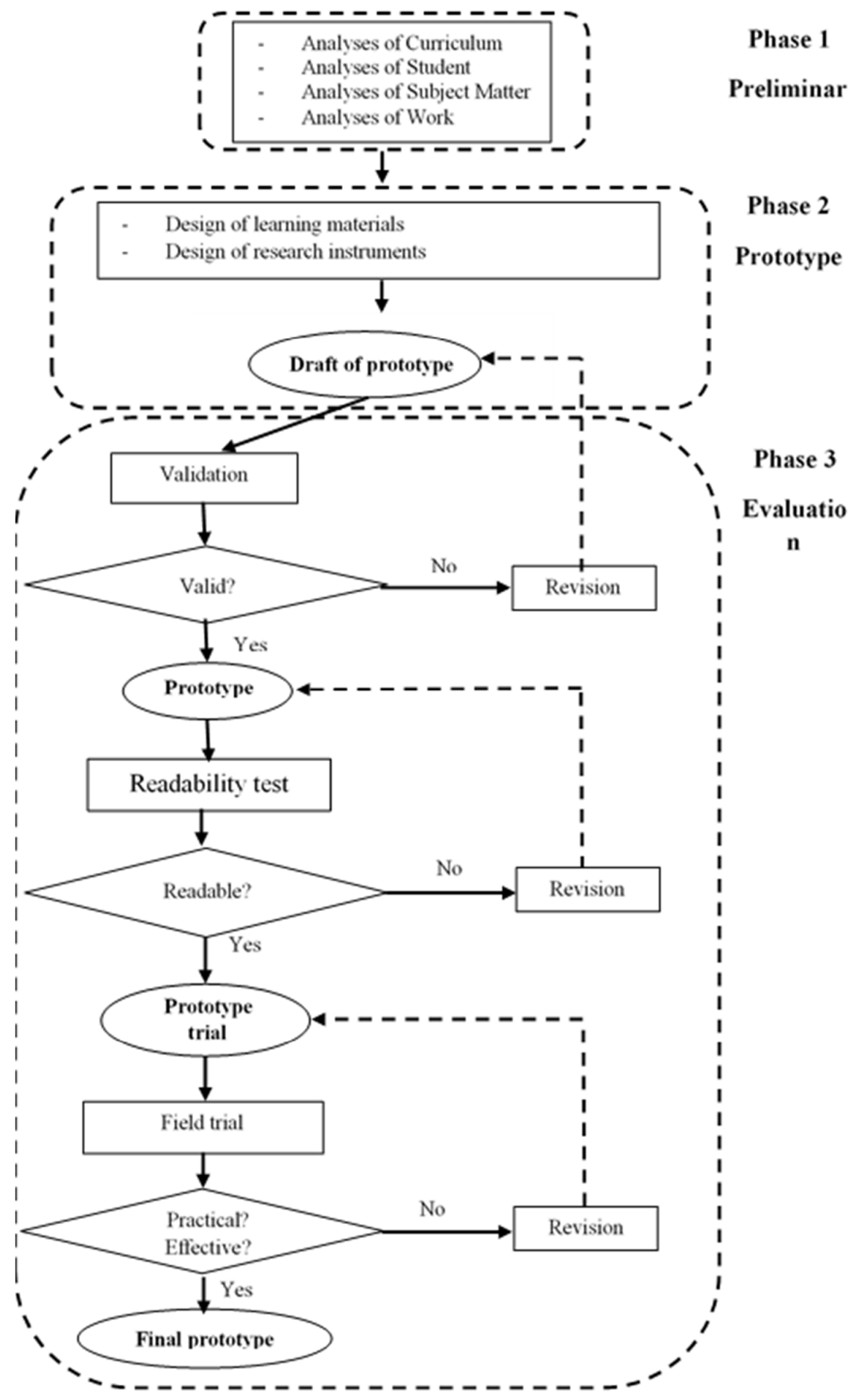

Figure 1. Flowchart of development planning

Int. J. Eval. \& Res. Educ. Vol. 8, No. 1, March 2019: 103 - 109 
Practicality seen from the consideration of experts and practitioners related materials (lesson plan) used whether complicate to students and teachers or not [20]. The practicality of this research is based on two things, that is, if both experts and practitioners reveal that the lesson plan can theoretically be used by teachers and students and its implementation is in good criteria. It is intended that teachers and students are able to carry out well planned activities [22].

The effectiveness of lesson plan is determined based on the student's response level in the learning activities and high student enthusiasm to follow the learning activities continuously [20]. Lesson plan is said to be effective, if the student's response to the learning activity is positive and the achievement of student learning completeness in classical, if $\geq 80 \%$ students complete their study.

\section{RESULTS AND DISCUSSION}

The lesson plan is developed based on four principles of FEM approach, which are simple, useful, relation, and fun, with the aim of helping students in understanding integer number operations in an easy, useful, meaningful, and fun way, and engaged students actively in classroom learning activities. In addition, it also used number line model in teaching the exact concept of integer number operations, in particular addition and subtraction of integers. This is intended to avoid the existence of mathematical manipulation, in which students are not only given knowledge directly or memorize it, but they are able to know the meaning of each learning process.

For example, if the student is asked to calculate the sum of addition $-2+(-3)=-5$, it is not obtained from memorizing the rule, if $(-)+(-)=(+)$, but derived from a meaningful process through the use of number line model based on patterns: (1) always start from 0, (2) arrow faces right, (3) positive number read forward, (4) negative number read back, (5) addition operation read as continue, and (6) subtraction operation read as turn right or left and continue.

The development of this lesson plan is focused on students at the fourth grade of primary school and its development is divided into three activities, namely introduction, core, and cover. Each of them is described in Table 1.

Table 1. Description of lesson plan development

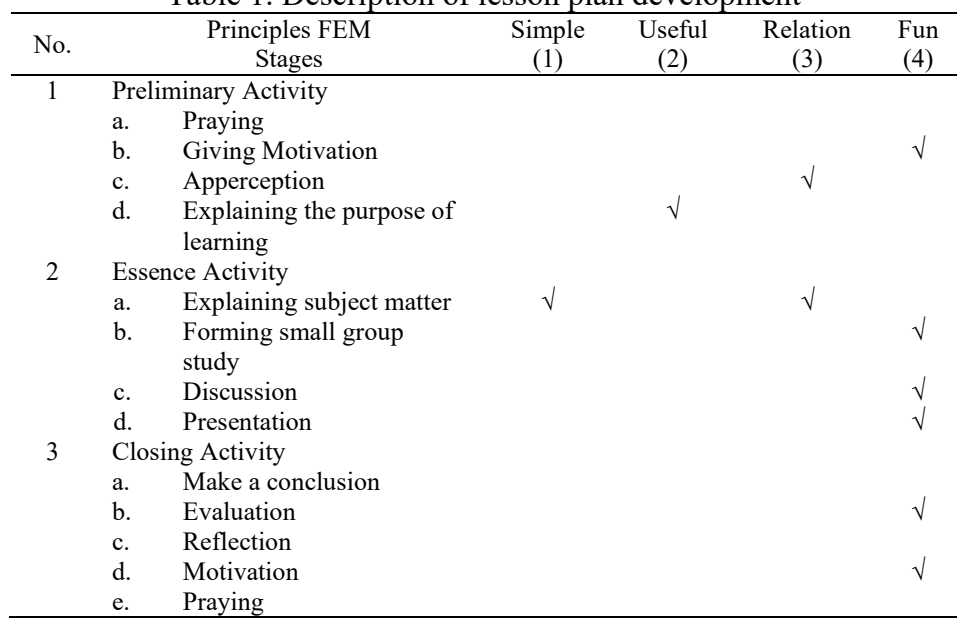

Each of the preliminary, essence, and closing activities contains the activities of teachers' and students' in the lesson as described in Table 2. Students worksheet for practise through the game "fast fight" is shown in Table 3. 
Table 2. Description of activities for each stage

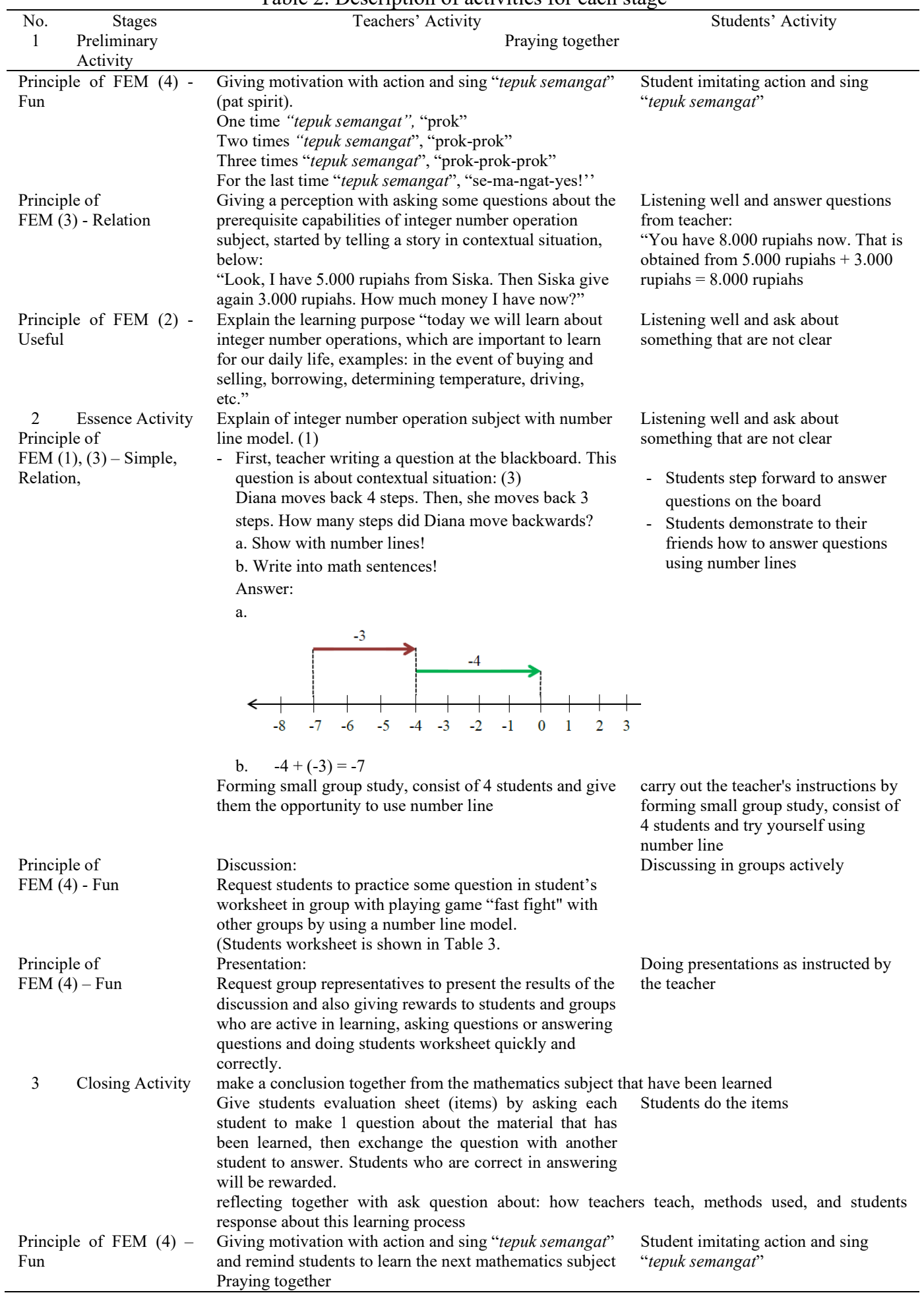

Int. J. Eval. \& Res. Educ. Vol. 8, No. 1, March 2019: 103 - 109 
Table 3. Student worksheet

\begin{tabular}{l} 
In the evening, Mrs. Rini drives her motorcycle to picks up Rendy who is involved in study group with his friends at \\
Perumahan Semeru Indah Blok G no. 3. However, Mrs. Rini arrives in the wrong address that is at home no. 5. What should \\
she do in order to arrive at home no. 3? \\
\hline a. What can be known and asked about the above problem? \\
b. How do you solve the problem above? \\
Answer: \\
Prove the solution to the problem above by writing a number line model demonstration \\
Based on the rules! \\
Answer:
\end{tabular}

\section{CONCLUSION}

Based on the result and discussion, it can be concluded that the development research with FEM approach assisted number line model can help students understand the right concept of integer number operation simply, useful, meaningfully, and fun. In other hand, it's expected to be a good way for teacher in creating of a conducive learning environment to involve student's actively in learning mathematics. It can be seen from the various activity of preliminary, essence, and closing. Therefore, a set of activities describe in role of teacher and students have been proposed for a better implementation of lesson plan to learn operation of integer number in classroom setting. In this developmental research, there were contextual situation, i.e. counting money etc. In addition, this research used the model that were related to the given contexts, namely number line model. So, by understanding the FEM approach and its implementation in the development of lesson plan, a new lesson plan which is innovative and creative can be built. Ultimately, I hope my research will contribute to that development.

\section{REFERENCES}

[1] Permendiknas, "Content Standards for Primary and Secondary Education Unit," Depdiknas, 2006.

[2] Fathani. A. H., "Mathematics Nature and Logic," Ar-Ruzz Media, 2009.

[3] Depdiknas, "Model of Development of Syllabus for Subjects and Plans for the Implementation of Integrated Science Learning," 2006.

[4] Darwis M., "Teaching Concepts in Mathematics (Especially in Middle and Higher Education)," Makalah Komprehensif Magister PPS IKIP Malang, 1992.

[5] Sudarminta. J., "Basic Epistemology," Kanisius, 2002.

[6] Ruhyana, "Analysis of Student difficulties in Mathematical Problem Solving," Jurnal Computech \& Bisnis, vol. 1(2), pp. 106-118, 2016.

[7] Mulyasa, "Becoming Professional Teacher," Remaja Rosdakarya, 2015.

[8] Muhseto. G., "Elementary Mathematics Learning," Universitas Terbuka, 2014.

[9] Fahrur, "The Amazing of Advanced Mathematics," Tim Matematika Dahsyat Indonesia, 2012.

[10] Jamaris. M., "New Orientation in Educational Psychology," Ghalia, 2013.

[11] Arsaythamby. V. and Zubainur. C. M., "How a Realistic Mathematics Educational Approach Affect Students' Activities in Primary Schools?," Social and Behavioral Science, vol.159, pp. 309-313, 2014.

[12] Parimsavad. S., "Creating a Joyful Learning Environment at Primary Level SPIJE," An International Journal of Education, vol. 4(1), pp. 10-14, 2014.

[13] Saifuddin, "Management of Theoretical and Practical Learning", Deepublish, 2014.

[14] Ozdogan. E., "Play, Mathematics, and Mathematical Play in Early Childhood Education", Procedia-Social and Behavioral Sciences, vol. 15(1), pp. 3118-3120, 2014.

[15] Siligar, E. I. P., Somakim, and Hapizah, "Learning the Permutation Concept through Role-Playing", Journal of Education and Learning (EduLearn), vol. 12(3), pp. 422-431, 2018

[16] Lucardie. D., "The Impact of Fun and Enjoyment on Adult's LearningProcedia", Social and Behavioral Science, vol. 142, pp. 439-446, 2014.

[17] Sanjaya. W., "Education Process Oriented Learning Strategies", Kencana Prenada Media Group, 2006.

[18] Kemdikbud, "Book of Natural Science Teachers", 2013.

[19] Plomp. T., "Educational Design Research", Netherlands Institute for Curriculum Development (SLO), 2013.

[20] Nieveen. N., "Prototyping to Research Product Quality, Design Approach and Tool in Education and Training", Kluwer Academic Publisher, 1999.

[21] Wallen. N. E. and Fraenkel. J. R., "How to Design and Evaluate Research in Education", McGraw-Hill, 2009.

[22] Hobri, "Development Research Methodology", Pene Salsabila, 2010. 